\title{
Analisis Pemakaian Listrik pada Pompa Drainage Unit dengan Menggunakan New Quality Tools
}

\author{
Firdanis Setyaning Handika*, Abdullah B. Barnadi \\ Program Studi Teknik Industri, Fakultas Teknik, Universitas Serang Raya \\ Email: firdanishandika@gmail.com; smkn212@gmail.com
}

\begin{abstract}
Abstrak - Setiap perusahaan berusaha meminimalkan biaya produksi untuk mendapatkan produk dengan harga bersaing. Sebuah perusahaan kimia di Cilegon mempunyai program penurunan biaya produksi. Namun dalam proses produksinya, masih ditemukan beberapa faktor yang menyebabkan tingginya biaya produksi terutama biaya listrik pada peralatan pompa. Penelitian ini bertujuan untuk mengetahui penyebab tingginya pemakaian listrik pada pompa drainage unit, memberikan usulan perbaikan, dan mengevaluasi hasil perbaikan. Penelitian ini menggunakan sebagian alat kualitas baru yang terdiri atas affinity diagram, interrelationship diagram, matrix diagram, tree diagram, dan Process Decision Program Chart (PDPC). Berdasarkan hasil penelitian diperoleh faktor yang menjadi penyebab tingginya pemakaian listrik pada pompa drainage unit yaitu DCS-Man lupa melakukan stop pada pompa G-1875, keluaran sealing C-1851 masuk ke dirty pit, dan keluaran sealing G-1871 masuk ke dirty pit. Langkah perbaikannya adalah memindahkan keluaran sealing C-1851 dari dirty ditch ke clean ditch, memindahkan keluaran sealing G-1871 dari dirty ditch ke clean ditch, memperbaiki kebocoran pada box sample product, dan pompa G-1875 dibuat auto start-stop. Perbaikan kendala tersebut mendapatkan hasil drainage unit beroperasi 2 kali per minggu dari sebelumnya 18 kali perminggu atau berkurang sebesar 89\% dan dapat menghemat sebesar Rp 1.677.205,- per tahun.
\end{abstract}

Kata kunci: Kualitas; Pompa; New Quality Tools

\begin{abstract}
Every company tries to minimize the cost of production to get the product with the price of flocking. A Chemical Company in Cilegon has a production cost reduction program. However, in the process of creation, still found some factors that cause high production costs, especially the cost of electricity in pumping equipment. This study aims to determine the causes of high electricity consumption in the drainage pump unit, provide suggestions for improvement and evaluate the results of revision. This research uses some new quality tools consisting of affinity diagrams, interrelationship diagrams, matrix diagrams, tree diagrams, and Process Decision Program Chart (PDPC). Based on the results of the research, the factors causing high electricity consumption in the drainage pump unit are DCS-Man forgot to stop at the G-1875 pump, the C-1851 sealing output goes to the slimy pit, and the G-1871 sealing output goes into the dirty hole. The remedial step is to move the $C-1851$ sealing output from the muddy ditch to the clean trench, moving the G-1871 sealing output from the filthy ditch to the clean ditch, fixing the leak in the sample product box, and the G-1875 pump made auto startstop. These drainage improvements resulted in drainage units operating two times per week from the previous 18 times per week or decreased by 89\% and can save as much as Rp 1,677,205 per year.
\end{abstract}

Keywords: Pump; Quality; New Quality Tools

\section{PENDAHULUAN}

Dewasa ini perkembangan Industri Kimia, Tekstil, dan Aneka (IKTA) di Indonesia sangat pesat. Kemenperin mencatat, pertumbuhan IKTA pada kuartal pertama tahun 2017 sebesar $5,16 \%$ atau naik $0,05 \%$ dibandingkan periode yang sama tahun 2016. Pesatnya pertumbuhan IKTA di Indonesia mewajibkan setiap perusahaan

$\begin{array}{lll}\text { Artikel masuk } & : & \text { 02 Desember } 2017 \\ \text { Artikel direvisi } & : & \text { 29 Desember } 2017 \\ \text { Artikel diterima } & : & \text { 30 Desember } 2017\end{array}$

- 30 Desember 2017

*Penulis Korespondensi untuk dapat menghasilkan produk yang berkualitas sesuai dengan spesifikasi pelanggan serta dalam pemenuhanya harus tepat waktu. Selain itu, perusahaan pun harus dapat berproduksi dengan biaya seminimal mungkin demi kelangsungan usahanya.

Sebuah perusahaan kimia yang berlokasi di Cilegon, Banten mempunyai target yang berkaitan dengan program penurunan biaya (Cost Reduction Program atau CRP) yang harus sejalan dengan target utama, yaitu Stabil 
Operasi. Permasalahan yang menjadi fokus dalam proses produksi adalah masih tingginya biaya unit produksi. Salah satu biaya yang paling tinggi adalah biaya listrik. Sedangkan penggunaan listrik yang paling tinggi adalah peralatan pompa dan setelah dianalisis pompa drainage unit adalah pompa periodik dengan konsumsi listrik terbesar, yaitu 2007,5 KW selama setahun.

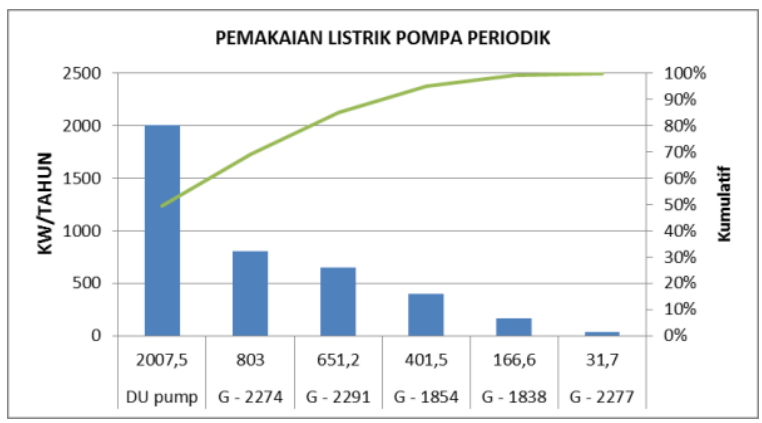

Gambar 1. Pemakaian listrik pompa periodic Sumber: Data Perusahaan (2017)

Seven basic quality tools, diperkenalkan oleh Kaoru Ishikawa pada tahun 1968, merupakan tujuh macam alat dan teknik yang berbentuk grafik untuk mengidentifikasi dan menganalisis permasalahan yang berkaitan dalam produksi. Seven Tools merupakan pendekatan kuantitatif dalam memecahkan permasalahan yang ada. Namun, pada perkembangannya seven basic quality tools sering berhadapan dengan permasalahan yang terjadi karena kompleksitasnya. Oleh karena itu, pada tahun 1972 diperkenalkan alat pengendali kualitas baru yang disebut dengan seven new quality tools atau seven management and planning tools.

Seven New Quality Tools adalah metode yang digunakan untuk memperbaiki kekurangan Seven Basic Quality Tools. New seven tools merupakan peralatan untuk memetakan permasalahan secara terperinci untuk membantu pengambilan keputusan dan memperlancar koordinasi kerja team (Fakhrudin, Harsono, \& Novirani, 2015). Metode ini digunakan sebagai alat untuk memetakan ruang lingkup persoalan, menyusun diagram data, menelusuri kemungkinan penyebab masalah dan memperjelas kenyataan suatu persoalan (Rachmadina \& WP, 2015), mempunyai karakteristik mendefinisikan data verbal, mengumpulkan data verbal, membangun ide dan memformulasikan dalam suatu rencana (Suci, Nasution, \& Rizki, 2017). Metode ini dapat digunakan untuk mengendalikan dan memperbaiki proses produksi sehingga bisa menurunkan biaya produksi.

Penelitian ini bertujuan untuk mengetahui penyebab tingginya pemakaian listrik pada pompa drainage unit. Dengan dilakukannya analisis tersebut menggunakan new quality tools diharapkan dapat mengurangi pemakaian listrik yang masih tinggi serta mendukung program penurunan biaya produksi.

\section{METODE PENELITIAN}

Penelitian dilakukan di sebuah perusahaan kimia di Daerah Cilegon, Banten. Langkah pertama dilakukan identifikasi tentang pemakaian raw material yang berlebih. Berdasarkan data budget unit konsumsi dalam periode April 2016 Maret 2017 raw material yang melebihi budget terbesar adalah listrik, dan pompa drainage unit adalah pemakai listrik terbesar di PTA-1 plant. Identifikasi mulai dari awal untuk memetakan masalah-masalah sampai dengan dirumuskan usulan perbaikan dengan menggunakan metode seven new quality tools.

Seven new quality tools adalah suatu metode yang digunakan untuk menangani data verbal, yang berbeda dengan data kuantitatif yang diselesaikan dengan seven basic quality tools (Kovach, Cudney, \& Elrod, 2011). Alat-alat kendali kualitas baru adalah affinity diagram, interrelationship diagram, tree diagram, matrix diagram, matrix data analysis, arrow diagram atau activity network diagram, dan Process Decision Program Chart (PDPC). Pada penelitian ini alat yang digunakan untuk pengolahan data hanya affinity diagram, interrelationship diagram, matrix diagram, tree diagram, dan Process Decision Program Chart (PDPC).

\section{Affinity Diagram}

Diagram afinitas adalah alat brainstorming grafis, digunakan untuk mengelompokkan fakta, pendapat, gagasan dan keinginan pelanggan sesuai dengan beberapa bentuk afinitas alami (Shahin, Arabzad, \& Ghorbani, 2010; Halim, et, al, 2017). Langkah yang dilakukan dalam tahapan ini adalah melakukan sesi curah pendapat (brainstorming) dan menuangkannya pada affinity diagam dengan cara mengelompokan variabel-variabel hasil brainstorming ke dalam kelompok-kelompok yang sesuai dengan hubungan naturalnya untuk mengetahui apa saja faktor penyebab tingginya unit konsumsi yang terpilih.

\section{Interrelationship Diagram}

Interrelationship Diagram adalah alat untuk mencari pemecahan masalah yang mempunyai hubungan yang kompleks (Widiaswanti, 2017). Interrelationship Diagram untuk mengklarifikasi 
masalah yang ada dengan asumsi penyebab yang mungkin terjadi dan menentukan strategi penyelesaian untuk penyebab masalah yang ada (Wisnubroto \& Rukmana, 2015). Penggunaan diagram ini bertujuan untuk mengetahui apa saja akar penyebab dominan yang menyebabkan tingginya unit konsumsi terpilih. Data yang digunakan dalam pembuatan interrelationship diagram ini diambil dari hasil affinity diagam yang sebelumnya telah dibuat.

\section{Matrix Diagram}

Setelah mengetahui apa saja akar penyebab dominan yang menyebabkan tingginya unit konsumsi terpilih melalui interrelationship diagram. Kemudian akar penyebab dominan tersebut dituangkan pada matrix diagram untuk mengetahui urutan penyebab dominannya dengan cara dinilai pada tiap-tiap akar penyebab dominan oleh para pekerja serta pembimbing lapangan berdasarkan tingkat keefektifitasan dikali dengan jumlah anak panah yang keluar dalam interrelationship diagram.

\section{Tree Diagram}

Tree diagram merupakan teknik untuk menyelesaikan suatu konsep seperti target, tujuan, persoalan, sasaran ke dalam sub-sub komponen, atau tingkat yang lebih rendah dan rinci. Tree diagram menghubungkan tujuan yang harus ditempuh dengan pelaksanaan tugas sesuai dengan tujuan yang akan di capai (Ariani, 2004). Tree diagram diawali satu item yang kemudian bercabang menjadi dua atau lebih, yang mana cabang tersebut membentuk cabang lagi sehingga tampak seperti pohon.

\section{Process Decision Program Chart (PDPC).}

Process Decision Program Chart adalah metode yang digunakan untuk mengidentifikasi masalah yang berpotensi terjadi dan melakukan rencana tindkan pencegahan (Chandradevi \& Puspitasari, 2016). Diagram PDPC bertujuan untuk mengantisipasi masalah yang mungkin akan terjadi dan memberi solusi penanggulangan yang bisa meminimalkan masalah terjadi lebih luas pada setiap cabang tree diagram

\section{HASIL DAN PEMBAHASAN}

Data awal dalam penelitian ini adalah data pemakaian listrik pada perusahaan kimia di Daerah Cilegon berdasarkan data budget unit konsumsi dalam periode April 2016 - Maret 2017. Berdasarkan data tersebut, pompa drainage unit menyumbang pemakaian listrik terbesar.

\section{Affinity Diagram}

Setelah memilih obyek penelitian, yaitu pompa drainage unit, penulis melakukan brainstorming bersama pembimbing lapangan dan para pekerja di PT Mitsubishi Chemical Indonesia mengenai faktor penyebab tingginya pemakaian listrik pompa drainage unit, kemudian data tersebut dikelompokan sesuai dengan hubungan naturalnya sehingga didapatkan beberapa faktor yang dapat digambarkan dalam affinity diagram seperti pada Gambar 1.

\begin{tabular}{|c|c|c|c|c|}
\hline \multicolumn{5}{|c|}{ Faktor Penyebab Tingginya Pemakaian Listrik pada Pompa Drainage Unit } \\
\hline Manusia & Mesin & Metode & Material & Lingkungan \\
\hline \multirow{5}{*}{$\begin{array}{l}\text { DCS-man lupa } \\
\text { stop pompa G- } \\
1875 \\
\\
\text { DCS-man terlalu } \\
\text { banyak aktifitas } \\
\text { yang dikontrol }\end{array}$} & 口 & E & E & 口 \\
\hline & $\begin{array}{l}\text { G-1875 lama } \\
\text { operasi }\end{array}$ & $\begin{array}{l}\text { Inspeksi screen } \\
\text { dilakukan saat } \\
\text { patrol }\end{array}$ & $\begin{array}{l}\text { TA menyumbat di } \\
\text { pipa G-1875 } \\
\text { menuju waste }\end{array}$ & \multirow{7}{*}{$\begin{array}{l}\square \begin{array}{l}\text { Frekuensi listrik } \\
(\mathrm{Hz}) \text { turun }\end{array} \\
\begin{array}{l}\text { Voltase listrik } \\
\text { turun }\end{array} \\
\square \text { Plant kotor } \\
\square \begin{array}{l}\text { Ada aktifitas } \\
\text { cleaning lantai }\end{array} \\
\square \text { Hujan }\end{array}$} \\
\hline & $\begin{array}{l}\text { Line G-1875 ke } \\
\text { WW Tank }\end{array}$ & Semua liquid & water tank & \\
\hline & clogging & masuk ke F-1875 & $\begin{array}{l}\text { Cairan yang di } \\
\text { transfer pekat }\end{array}$ & \\
\hline & G-1875 kavitasi & 1875 & $\begin{array}{l}\text { karna tercampur } \\
\text { TA }\end{array}$ & \\
\hline & $\begin{array}{l}\text { Box sample } \\
\text { produk bocor } \\
\text { sehingga TA } \\
\text { keluar }\end{array}$ & $\begin{array}{l}\text { Keluaran sealing } \\
\text { C-1851 dimasukan } \\
\text { ke dirty ditch }\end{array}$ & $\begin{array}{l}\text { Banyak Foreign } \\
\text { material di F-1875 }\end{array}$ & \\
\hline & 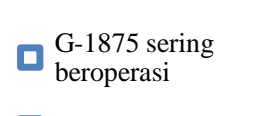 & $\begin{array}{l}\text { Keluaran sealing } \\
\text { G-1871 dimasukan } \\
\text { ke dirty ditch }\end{array}$ & $\begin{array}{l}\text { Banyak liquid } \\
\text { yang masuk ke F- } \\
1875\end{array}$ & \\
\hline & Alat di plant bocor & $\begin{array}{l}\text { Operasi G-1875 } \\
\text { dilakukan secara } \\
\text { manual. }\end{array}$ & $\begin{array}{l}\text { Level F-1875 } \\
\text { sering tinggi }\end{array}$ & \\
\hline
\end{tabular}

Gambar 1. Affinity Diagram Penyebab Tingginya Pemakaian Listrik pada Pompa Drainage Unit 
Berdasarkan Gambar 1 diketahui bahwa terdapat 5 faktor penyebab terjadinya pemakaian listrik yang tinggi pada pompa drainage unit, yaitu: manusia, mesin, metode, material, dan lingkungan, dimana masing-masing faktor penyebab mempunyai variabel. Variabel-variabel tersebut selanjutnya akan dicari hubungan antara satu variabel dengan variabel lainnya.

\section{Interrelationship diagram}

Interrelationship diagram digunakan untuk menunjukkan hubungan antar variabel penyebab tingginya pemakaian listrik pada pompa drainage unit seperti yang ditunjukan pada Gambar 2. Berdasarkan Gambar 2 diketahui bahwa variabel DCS-Man lupa stop pompa G-1875, keluaran sealing C-1851 masuk ke dirty pit, dan keluaran sealing G-1871 masuk ke dirty pit memiliki arrow out tiga atau lebih merupakan variabel yang dianggap menjadi akar penyebab dari tingginya pemakaian listrik pada pompa drainage unit.

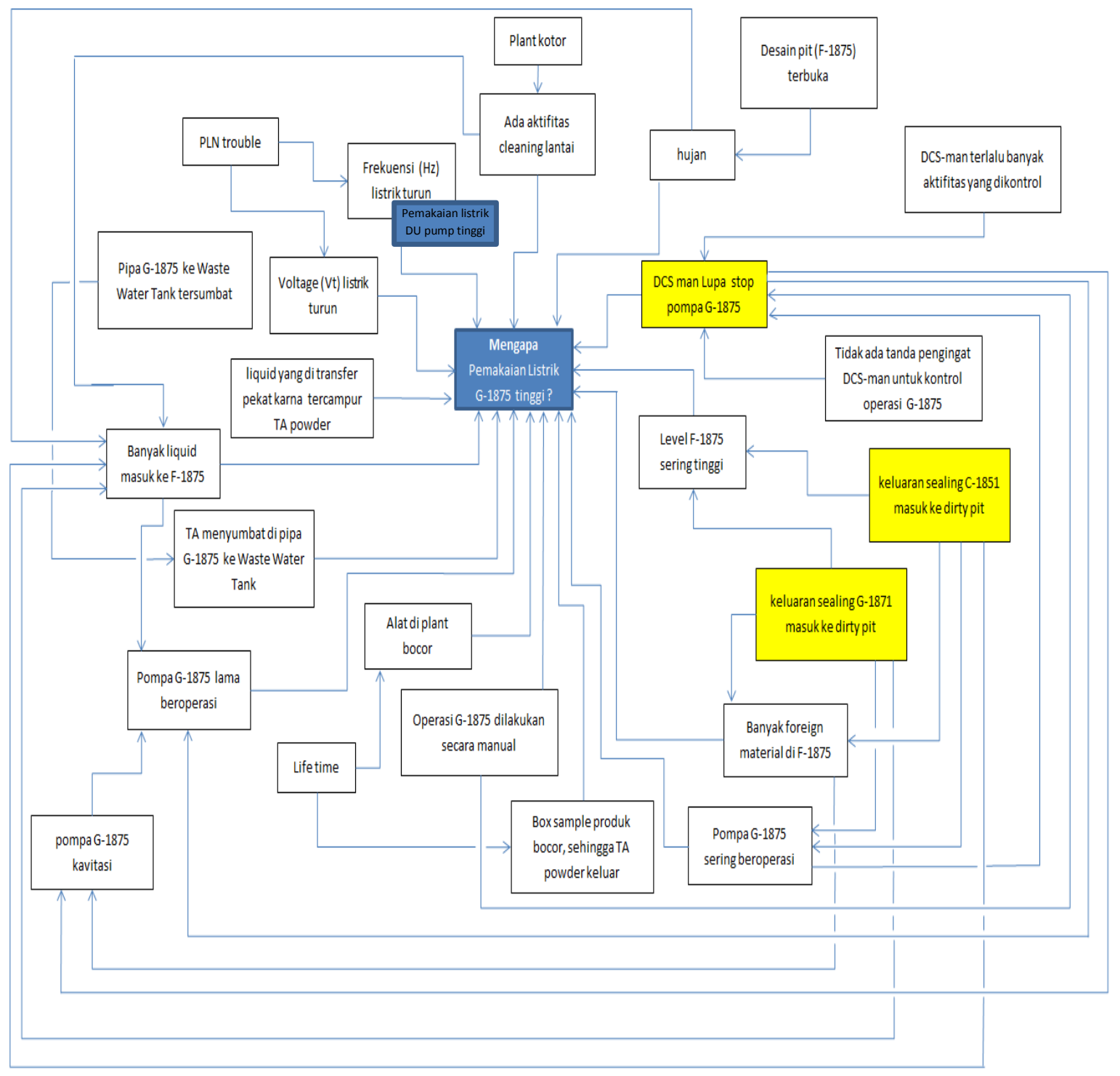

Gambar 2. Interrelationship Diagram Antar Variabel Penyebab Tingginya Pemakaian Listrik pada Pompa Drainage Unit 
Tabel 1. Matrix Diagram Penyebab Tingginya Pemakaian Listrik pada Pompa Drainage Unit

\begin{tabular}{llllll}
\hline & & \multicolumn{4}{c}{ Penyebab } \\
\cline { 3 - 6 } No. Anggota & $\begin{array}{l}\text { Keluaran sealing G- } \\
1871 \text { dimasukkan ke } \\
\text { dirty ditch }\end{array}$ & $\begin{array}{l}\text { Keluaran sealing C- } \\
1851 \text { dimasukkan ke } \\
\text { dirty ditch }\end{array}$ & $\begin{array}{l}\text { DCS Man } \\
\text { stop pompa } \\
\text { G-1875 }\end{array}$ \\
\hline 1 & NIM & E/P & $2 / 4$ & $3 / 4$ & $2 / 3$ \\
\hline 2 & YYT & E/P & $2 / 4$ & $3 / 4$ & $2 / 3$ \\
\hline 3 & NNG & E/P & $2 / 4$ & $3 / 4$ & $2 / 3$ \\
\hline 4 & WHY & E/P & $2 / 4$ & $3 / 4$ & $2 / 3$ \\
\hline 5 & ABB & E/P & $2 / 4$ & $3 / 4$ & $2 / 3$ \\
\hline \multicolumn{3}{l}{ Total (E/P) } & $10 / 20$ & $15 / 20$ & $10 / 15$ \\
\hline Score (E*P) & 200 & 300 & 150 \\
\hline
\end{tabular}

Dimana:

$$
\begin{array}{ll}
\mathrm{E} & =\text { efikasi / efektifitas / kemampuan } \\
\text { untuk mencapai hasil yang diinginkan }
\end{array}
$$

Berdasarkan Tabel 1 diketahui bahwa urutan penyebab-penyebab dominan yang meyebabkan pemakaian listrik pada pompa drainage unit tinggi adalah sebagai berikut:

1) Keluaran sealing $\mathrm{C}-1851$ dimasukkan ke dirty ditch dengan skor 300 ;

2) Keluaran sealing G-1871 dimasukkan ke dirty ditch dengan skor 200;

3) DCS-Man lupa stop pompa G-1875 dengan skor 150.

\section{Tree diagram}

Tree diagram digunakan untuk memecahkan suatu konsep atau aktivitasaktivitas secara lebih terperinci ke dalam sub-sub komponen atau tingkat yang lebih rendah dan terperinci lagi. Berdasarkan hasil wawancara dan diskusi dengan pihak pembimbing lapangan dan para karyawan PT Mitsubishi Chemical Indonesia divisi Manufacturing seksi PRO-TPA1 didapatkan beberapa informasi mengenai beberapa alternatif yang dapat dilakukan untuk mengurangi pemakaian listrik pada pompa drainage unit. Gambar 3 merupakan tree diagram terkait dengan beberapa alternatif pencapaian yang dapat dilakukan untuk mengurangi pemakaian listrik pada pompa drainage unit beserta breakdown untuk setiap alternatif berdasarkan levelnya. Gambar 2 diketahui bahwa variabel DCS-Man lupa stop pompa G-1875, keluaran sealing C-1851 masuk ke dirty pit, dan keluaran sealing G-1871 masuk ke dirty pit memiliki arrow out tiga atau lebih merupakan variabel yang dianggap menjadi akar penyebab dari tingginya pemakaian listrik pompa drainage unit.

\section{Matrix diagram}

Dari interrelationship diagram pada Gambar 2, yang memiliki arrow out tiga atau lebih diperoleh tiga calon penyebab dominan, dan dengan matrix diagram diperoleh peringkat seperti yang ditunjukan pada Tabel 1 .

Berdasarkan Gambar 3 dapat diketahui bahwa untuk mengurangi pemakaian listrik pompa drainage unit terdapat beberapa alternatif pencapaian yaitu manage pada manusia, perbaikan metode, menjaga kondisi mesin, manage material yang akan dikirim oleh G-1875, dan menjaga lingkungan tanpa pemborosan. Dari masing-masing alternatif tersebut dikembangkan lagi menjadi beberapa level yang merupakan solusi untuk melakukan improvement. Hasil dari tree diagram tersebut, diperoleh usulan perbaikan yang dapat mengurangi pemakaian listrik pada pompa drainage unit, yaitu:

1) Pindahkan keluaran sealing C-1851 dari dirty ditch ke clean ditch

2) Pindahkan keluaran sealing G-1871 dari dirty ditch ke clean ditch

3) Modifikasi pompa G-1875 menjadi auto startstop

4) Perbaiki kebocoran pada box sample product

Process Decision Program Chart (PDPC)

Process Decision Program Chart (PDPC) 
hampir sama dengan tree diagram. PDPC menggunakan cabang tree diagram sebagai dasar analisis tindakan penanggulangan agar masalah tidak berkembang luas. Kemudian pada akhir proses diberikan simbol yaitu O jika upaya penanggulangan dapat dilakukan dan simbol $X$ jika upaya penanggulangan sulit untuk dilakukan. Adapun PDPC untuk improvement mengurangi pemakaian listrik pompa drainage unit dapat ditampilkan seperti pada Gambar 4.

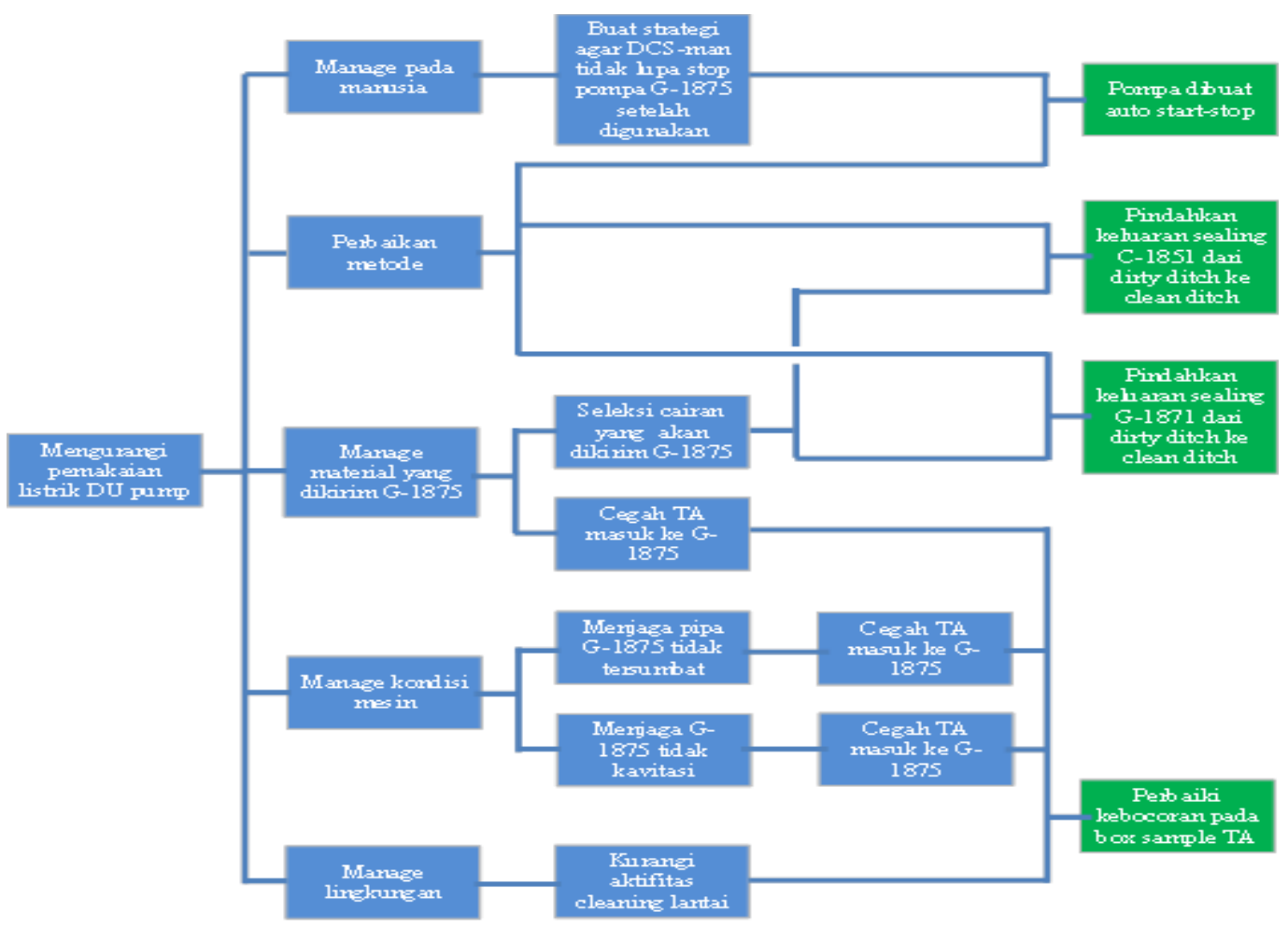

Gambar 3. Tree Diagram Alternatif Pencapaian untuk Mengurangi Pemakaian Listrik pada Pompa Drainage Unit

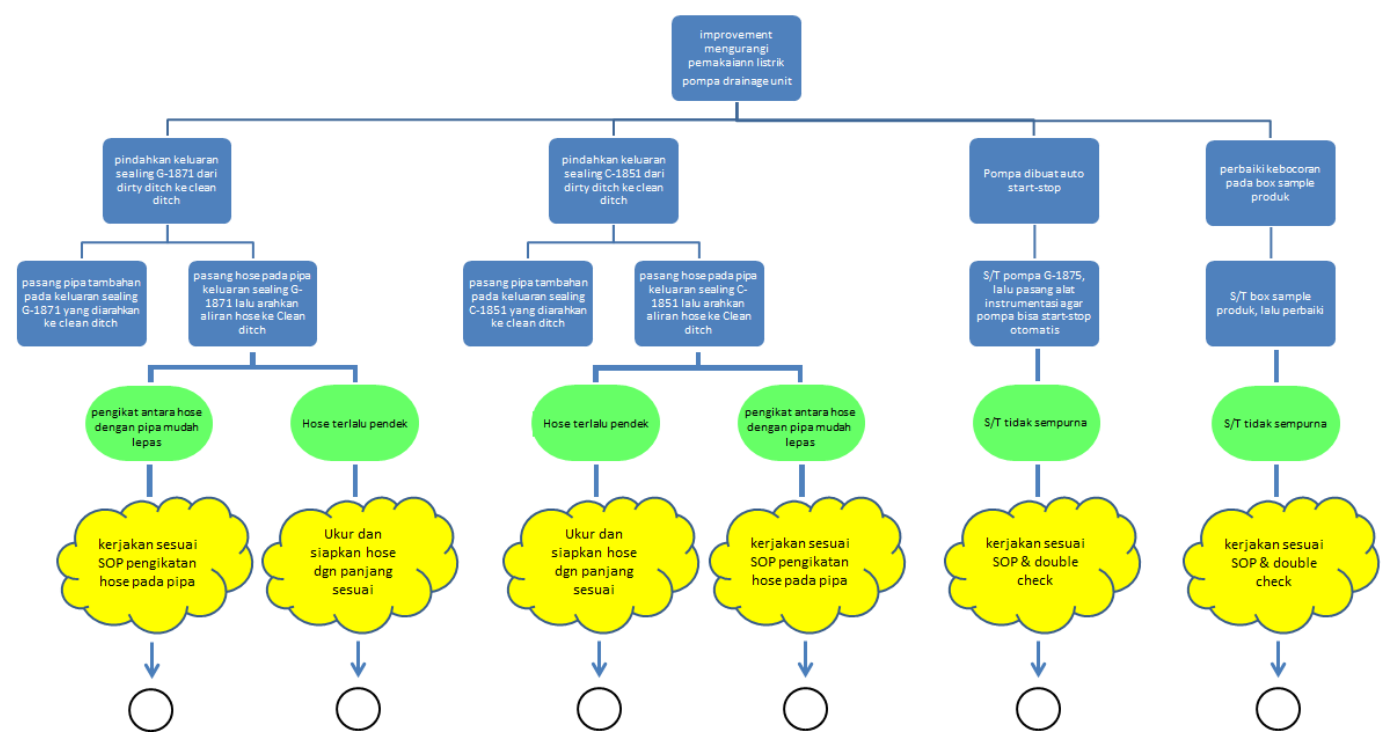

Gambar 4. Process Decision Program Chart (PDPC) untuk Mengurangi Pemakaian Listrik pada Pompa Drainage Unit 
Dari Gambar 4 diketahui rencana perbaikan, masalah potensial yang akan terjadi, dan cara penanggulangannya berdasarkan usulan yang didapatkan dari tree diagram.

1) Memindahkan keluaran sealing C-1851 dari dirty ditch ke clean ditch

a) Rencana perbaikan: memasang hose pada pipa keluaran sealing C-1851 dan diarahkan ke clean ditch.

b) Masalah potensial: hose terlalu pendek dan pengikat antara hose dan pipa mudah lepas

c) Cara penanggulangan: mengukur dan menyiapkan hose dengan panjang yang sesuai, serta mengerjakan sesuai SOP pengikatan hose pada pipa saat melakukan pengikatan.

2) Memindahkan keluaran sealing G-1871 dari dirty ditch ke clean ditch

a) Rencana perbaikan: memasang hose pada pipa keluaran sealing G-1871 dan diarahkan ke clean ditch

b) Masalah potensial: hose terlalu pendek serta pengikat antara hose dan pipa mudah lepas

c) Cara penanggulangan: mengukur dan menyiapkan hose dengan panjang yang sesuai, serta mengerjakan sesuai SOP pengikatan hose pada pipa saat melakukan pengikatan.

3) Memodifikasi pompa G-1875 dari manual menjadi auto start-stop

a) Rencana perbaikan: S/T pompa G-1875 lalu memasang alat instrumentasi

b) Masalah potensial: S/T G-1875 tidak sempurna

c) Cara penanggulangan: mengerjakan sesuai SOP dan double check pekerjaan yang telah dilakukan.

4) Memperbaiki kebocoran pada box sample product

a) Rencana perbaikan: $\mathrm{S} / \mathrm{T}$ box sample lalu memperbaiki.

b) Masalah potensial: S/T box sample tidak sempurna

c) Cara penanggulangan: mengerjakan sesuai SOP dan double check pekerjaan yang telah dilakukan.

Implementasi dari perbaikan yang telah dilakukan dapat diperoleh hasil bahwa drainage unit beroperasi 2 kali per minggu dari sebelumnya beroperasi 18 kali per minggu atau berkurang sebesar $89 \%$ seperti terlihat pada Gambar 5. Selain itu, sebelum dilakukan perbaikan, drainage unit mengkonsumsi listrik 2.007,5 KW per tahun dan setelah dilakukan perbaikan mengkonsumsi listrik 223,05 KW per tahun atau menghemat $1.784,45 \mathrm{KW}$ per tahun sesuai dengan Gambar 6. Sebelum dilakukan perbaikan, pompa drainage unit mengkonsumsi biaya listrik sebesar $\mathrm{Rp}$ 1.886.849,- per tahun dan setelah dilakukan perbaikan sebesar $\mathrm{Rp}$ 209.644,- per tahun atau menghemat $\mathrm{Rp}$ 1.677.205,- per tahun seperti yang terlihat pada Gambar 7.

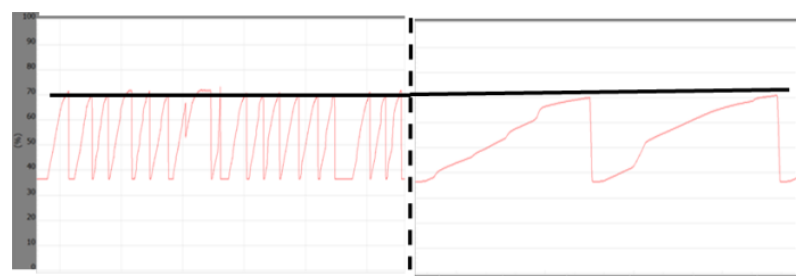

Gambar 5. Trend Frekuensi Start-Stop Pompa Drainage Unit Sebelum dan Setelah Perbaikan

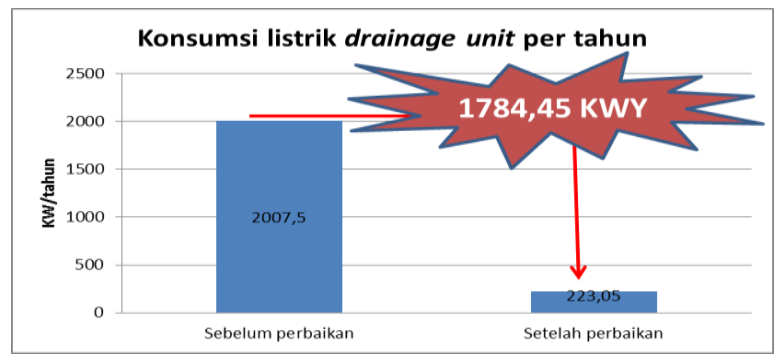

Gambar 6. Perbandingan Konsumsi Listrik Pompa Drainage Unit per Tahun Sebelum dan Setelah Perbaikan

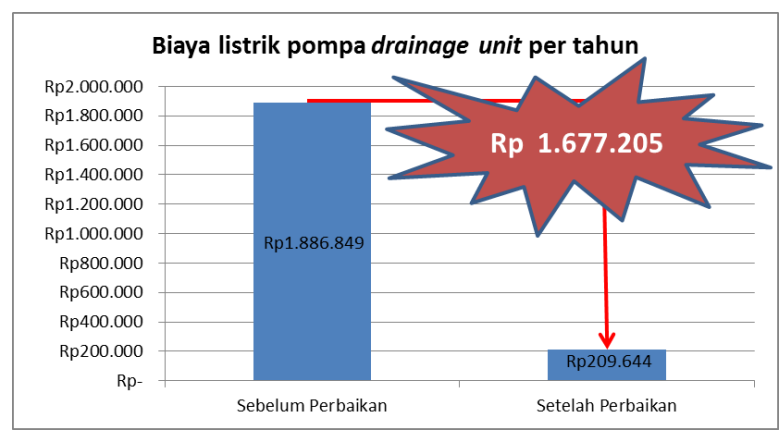

Gambar 7. Perbandingan Biaya Listrik Pompa Drainage Unit per Tahun Sebelum dan Setelah Perbaikan

\section{KESIMPULAN}

Berdasarkan pengolahan data yang telah dilakukan, diperoleh hasil bahwa terdapat tiga akar penyebab dominan yang mengakibatkan tingginya pemakaian listrik pompa drainage unit, yaitu DCS-Man lupa stop pompa G-1875, keluaran sealing C-1851 masuk ke dirty pit, dan keluaran sealing G-1871 masuk ke dirty pit. 
Usulan perbaikan guna menurunkan pemakaian listrik pompa drainage unit, yaitu memindahkan keluaran sealing C-1851 dari dirty ditch ke clean ditch, memindahkan keluaran sealing G-1871 dari dirty ditch ke clean ditch, memperbaiki kebocoran pada box sample product, dan membuat pompa G-1875 dapat melakukan auto start-stop. Perbaikan sistem operasi pompa drainage unit mempunyai pengaruh terhadap pemakaian listrik.

\section{DAFTAR PUSTAKA}

Ariani, D. W. (2004). Pengendalian kualitas Statistik (Pendekatan Kuantitatif dalam Manajemen Kualitas). Yogyakarta: Andi.

Chandradevi, A., \& Puspitasari, N. B. (2016). Analisa Pengendalian Kualitas Produksi Botol X 500 Ml Pada PT. Berlina, Tbk Dengan Menggunakan Metode New Seven Tools. Industrial Engineering Online Journal, 5(4), 1-9.

Fakhrudin, F. D. F., Harsono, A., \& Novirani, D. (2015). Usulan Perbaikan Peningkatan Kualitas Proses Pengisian Tabung Gas Elpiji 3 KG Menggunakan Six Sigma. REKA INTEGRA, 3(2), 399-409.

Halim Lim, S. A., Antony, J., Arshed, N., \& Albliwi, S. (2017). A systematic Review of Statistical Process Control Implementation in The Food Manufacturing Industry. Total Quality Management \& Business Excellence, 28(1-2), 176-189.

Kovach, J. V, Cudney, E. A., \& Elrod, C. C. (2011). The Use of Continuous Improvement Techniques: A Survey-Based Study of Current Practices. International Journal of Engineering, Science and Technology, 3(7), 89-100.

Rachmadina, D. P., \& WP, S. N. (2015). Analisis Penyebab Cacat pada Penyetripan Obat $X$ di PT. Xyz Menggunakan New Seven Tools. Industrial Engineering Online Journal, 4(4), $1-10$.

Shahin, A., Arabzad, S. M., \& Ghorbani, M. (2010). Proposing an Integrated Framework of Seven Basic and New Quality Management Tools and Techniques: A roadmap. Research Journal of International Studıes-Issue, 5(17), 183-194.

Suci, Y. F., Nasution, Y. N., \& Rizki, N. A. (2017). Penggunaan Metode Seven New Quality Tools dan Metode DMAIC Six Sigma Pada Penerapan Pengendalian Kualitas Produk (Studi Kasus: Roti Durian Panglima Produksi PT. Panglima Roqiiqu Group Samarinda). Jurnal EKSPONENSIAL, 8(1), 27-36.

Widiaswanti, E. (2017). Penggunaan Metode
Statistical Quality Control (SQC) untuk Pengendalian Kualias Produk. Jurnal Industri Inovatif, 4(2), 6-12.

Wisnubroto, P., \& Rukmana, A. (2015). Pengendalian Kualitas Produk dengan Pendekatan Six Sigma dan Analisis Kaizen Serta New Seven Tools sebagai Usaha Pengurangan Kecacatan Produk. Jurnal Teknik Industri, 8(1), 65-74. 